International Journal of Economics, Business and Accounting Research (IJEBAR)

Peer Reviewed - International Journal

Vol-4, Issue-1, 2020 (IJEBAR)

E-ISSN: 2614-1280 P-ISSN 2622-4771

https://jurnal.stie-aas.ac.id/index.php/IJEBAR

\title{
HOW COMPENSATION AND MOTIVATION GIVE IMPACT TO EMPLOYEE PERFORMANCE?
}

\author{
Gusti Noorlitaria Achmad ${ }^{1}$, Fitriansyah ${ }^{2}$ \\ Magister Manajemen Fakultas Ekonomi Dan Bisnis Universitas Mulawarman ${ }^{1}$ \\ Universitas Muhammadiyah Kalimantan Timur ${ }^{2}$ \\ E-mail: gusti.noorlitaria.achmad@feb.unmul.ac.id
}

\begin{abstract}
The success of a company is influenced by employee performance. By improving employee performance will make it easier for company goals to be achieved. One factor that can improve employee performance is the provision of compensation and motivation. This study aims to determine and analyze the effect of compensation and work motivation on employee performance. The sampling technique used is by taking a purposive sampling. The method used in this research is data collection through questionnaires, literature study, and observation. The technique used to analyze simple linear regression data and examine hypotheses simultaneously and partially. The result is compensation and motivation significantly influence employee performance simultaneously.
\end{abstract}

Keywords: $\quad$ compensation, motivation, employee performance.

\section{Introduction}

In achieving the company goals, the company does not only rely on the modern equipment and adequate facilities, but it will rely more on the people who do the work. Therefore, human resource, precisely the employees, plays very important role to achieve company goal. In each organization or company will try to improve the performance of its employees, hoping that the company goal will be achieved. To achieve good employee performance, it will not run easily because employee performance can happen if factors that have an influence such as compensation and work motivation can be felt well and are accepted by all employees in an organization or company.

One way to improve employee performance is by giving appreciation such as compensation as a result of compensation from all businesses that have been given to the company. Compensation has an important impact on employees to trigger employee performance so that they can always be at the highest level in accordance with individual abilities. The role of compensation is quite influential in forming potential employees. A high and relevant level of compensation will affect employee performance. Compensation is very important for employees so that they will be able to meet their needs and be able to improve their welfare.

Leader should strive for employees to have high motivation in carrying out every task and work because it can encourage employee to always work harder and provide all abilities and skills for the achievement of company goals. Employee work motivation is very important, because it is expected that each individual employee will work harder and be enthusiastic to achieve high performance in the future. Automotive is a business engaged in vehicles, especially motorbikes and cars. Labors in the automotive sector certainly "must have a high level of 
International Journal of Economics, Business and Accounting Research (IJEBAR)

Peer Reviewed - International Journal

Vol-4, Issue-1, 2020 (IJEBAR)

E-ISSN: 2614-1280 P-ISSN 2622-4771

https://jurnal.stie-aas.ac.id/index.php/IJEBAR

performance, one of which can be done by providing compensation and increasing work motivation.

\section{Literature Review}

Contains a theoretical foundation. This section contains previous literature related to research.

\section{Compensation}

According to Hariandja in Suwati (2013) compensation is something that employees receive in lieu of their service contribution to the company in the form of money or other forms which can be in the salaries, bonuses, incentives, benefits, health, food allowances, etc.

\section{Motivation}

According to Hasubian (2012:143) motivation is the complex of forces starting and keeping a person at work in an organization so that they want to cooperate with each other, work effectively, and be integrated with all their efforts to achieve satisfaction.

Motivation according to Ranupandojo and Hasan in Abrivianto et al. (2014) is the set of forces that initiate, directing and keep people in their efforts to achieve goals.

\section{Employee Performance}

As stated by Hasibuan (2012:94) employee performance can be interpreted as an individual work achievement in performing their duties in accordance with the responsibilities given to him based on experience, skills, sincerity and time.

Abdullah (2014:3) stated that employee performance is the result of work achieved by an employee in performing their duties.

According to Colquitt, LePine, and Wesson in Wibowo (2016:2) performance is a value of employee behaviours that contribute positively or negatively, in achieving organizational goals.

\section{Conceptual Framework}

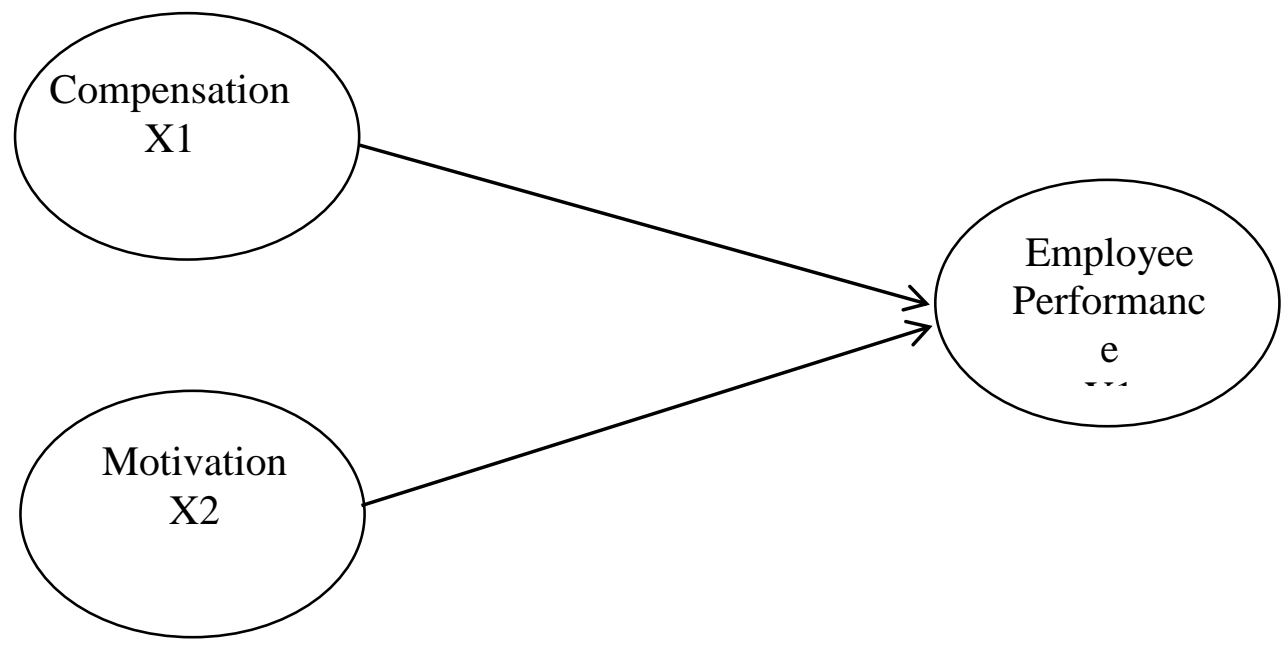

Figure 1. Coneptual Framework Model 
International Journal of Economics, Business and Accounting Research (IJEBAR)

Peer Reviewed - International Journal

Vol-4, Issue-1, 2020 (IJEBAR)

E-ISSN: 2614-1280 P-ISSN 2622-4771

https://jurnal.stie-aas.ac.id/index.php/IJEBAR

\section{Hypothesis}

Hypothesis a supposition explanation made on the basis of limited evidence as a starting point for further investigation. (Sugiyono, 2012: 93). From the description of the framework and the results of existing empirical studies, several hypotheses in this study can be proposed as follows:

$\mathrm{H}_{1} \quad$ : There is a positive and significant effect between motivation on employee performance

$\mathrm{H}_{2} \quad$ : There is a positive and significant effect between compensation on employee performance

\section{Research Method}

\section{Sample and Population}

Population and Research Samples Populations and samples used in this study are as follows:

1. Population is defined as the overall subject of the study within a specified scope and time (Kasmadi and Sunariah, 2013,: 65). The population used is employees from the automotive sector.

2. The sample technique used is called saturated sampling technique or total sampling technique. Based on this technique, the number of samples used in this study are 35 respondents.

\section{Sources and Types of Data}

Data Types

a. Qualitative data, collected data in the form of information, both orally and in writing relating to the problems of study.

b. Quantitative data, i.e. collected data in the form of numbers that are calculated relating to the problems of study.

\section{Data Sources}

a. Primary data, is research data collected directly from the original source, this data is collected by distributing questionnaires to respondents. In this study primary data includes data from the distribution of questionnaires to respondents

b. Secondary Data, i.e. data collected indirectly or through other parties or history reports that have been compiled in archives that are published or not

\section{Data Analysis}

Quantitative Analysis is a data analysis method that requires statistical and mathematical calculations. To simplify the analysis, SPSS version 22 is used. 
International Journal of Economics, Business and Accounting Research (IJEBAR)

Peer Reviewed - International Journal

Vol-4, Issue-1, 2020 (IJEBAR)

E-ISSN: 2614-1280 P-ISSN 2622-4771

https://jurnal.stie-aas.ac.id/index.php/IJEBAR

\section{Results and Discussion}

\section{Simple Linear Regression Results}

Regression

\begin{tabular}{|c|c|c|c|}
\hline & Mean & $\begin{array}{l}\text { Std. } \\
\text { Deviation }\end{array}$ & $\mathrm{N}$ \\
\hline $\begin{array}{l}\text { PERFORMA } \\
\text { NCE } \\
\text { COMPENSA } \\
\text { TION } \\
\text { MOTIVATIO } \\
\mathrm{N}\end{array}$ & $\begin{array}{l}4.171 \\
4 \\
5.771 \\
4 \\
7.085 \\
7\end{array}$ & $\begin{array}{l}1.94763 \\
2.10162 \\
2.04898\end{array}$ & 35 \\
\hline
\end{tabular}

The Descriptive Statistics table shows that the average (mean) performance of 35 employees is 4.1714 with a standard deviation of 1.94763, an average compensation of 5.7714 with a standard deviation of 2.10162, and motivation with an average of 7.0857 with a standard deviation of 2.04898 .

\begin{tabular}{|c|c|c|c|c|}
\hline \multicolumn{5}{|c|}{ Correlations } \\
\hline & & $\begin{array}{l}\text { PERFORMA } \\
\text { NCE }\end{array}$ & $\begin{array}{l}\text { COMPENSATI } \\
\text { ON }\end{array}$ & $\begin{array}{l}\text { MOTIVATI } \\
\text { ON }\end{array}$ \\
\hline \multirow[t]{3}{*}{$\begin{array}{l}\text { Pearson } \\
\text { Correlation }\end{array}$} & $\begin{array}{l}\text { PERFORMAN } \\
\text { CE }\end{array}$ & 1.000 & .779 & .726 \\
\hline & $\begin{array}{l}\text { COMPENSATI } \\
\text { ON }\end{array}$ & .779 & 1.000 & .913 \\
\hline & MOTIVATION & .726 & .913 & 1.000 \\
\hline \multirow[t]{3}{*}{ Sig. (1-tailed) } & $\begin{array}{l}\text { PERFORMAN } \\
\text { CE }\end{array}$ & & .000 & .000 \\
\hline & COMPENSATI & .000 & & .000 \\
\hline & & & & \\
\hline \multirow[t]{3}{*}{$\mathrm{N}$} & $\begin{array}{l}\text { PERFORMAN } \\
\text { CE }\end{array}$ & 35 & 35 & 35 \\
\hline & $\begin{array}{l}\text { COMPENSATI } \\
\text { ON }\end{array}$ & 35 & 35 & 35 \\
\hline & MOTIVATION & 35 & 35 & 35 \\
\hline
\end{tabular}

In the correlations table, the correlation or relationship between the three variables is the compensation variable with the performance collected $r=0.779$ with probability $=0.000<0.05$ then $\mathrm{Ho}$ is rejected, which means that there is a significant correlation between the compensation and the performance scores. Variable frequency of motivation with performance $r$ $=0.726$ 
International Journal of Economics, Business and Accounting Research (IJEBAR)

Peer Reviewed - International Journal

Vol-4, Issue-1, 2020 (IJEBAR)

E-ISSN: 2614-1280 P-ISSN 2622-4771

https://jurnal.stie-aas.ac.id/index.php/IJEBAR

Variables Entered/Removed ${ }^{\mathrm{a}}$

\begin{tabular}{|l|l|l|l|}
\hline $\begin{array}{l}\text { Mod } \\
\text { el }\end{array}$ & $\begin{array}{l}\text { Variable } \\
\text { Variables } \\
\text { Entered }\end{array}$ & $\begin{array}{l}\text { Remove } \\
\mathrm{d}\end{array}$ & Method \\
\hline 1 & $\begin{array}{l}\text { MOTIVAT } \\
\text { ION, } \\
\text { COMPEN } \\
\text { SATION }\end{array}$ & & \\
& & Enter \\
\hline
\end{tabular}

a. Dependent Variable: PERFORMANCE

b. All requested variables entered.

This Variable Entered / Removed table explains the variables that are entered or discarded and the methods used. In this case, the variables included are compensation and motivation variables as predictors and the method used is enter.

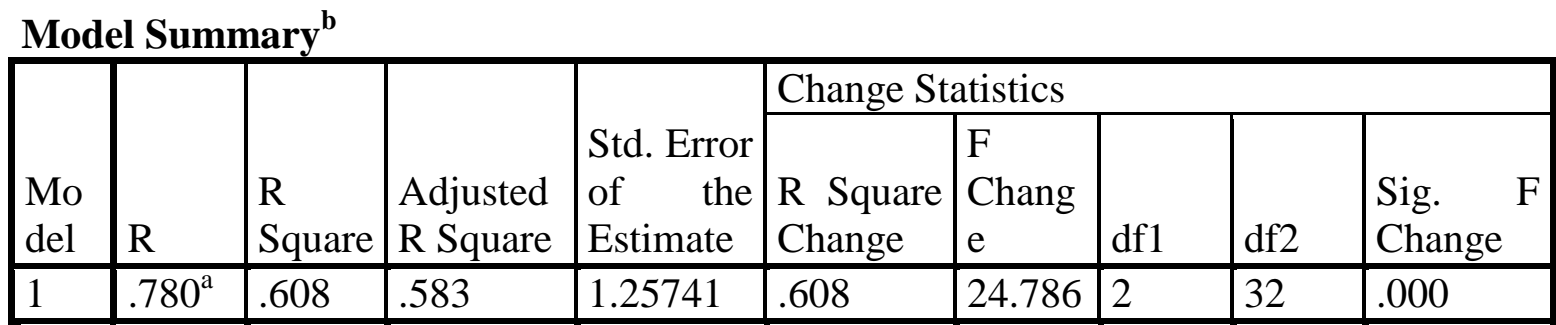

a. Predictors: (Constant), MOTIVATION, COMPENSATION

b. Dependent Variable: PERFORMANCE

In this table, it shows that the R-square 0.608 or $60.8 \%$. Which shows that the regression model can explain or describe the data behavior of $60.8 \%$ and the rest is influenced by other variables or in other words, the compensation variable can be explained by the motivational variable of 60.8 the remaining\% is $39.2 \%$. The standard error of the estimate in this table is 1.25741 on the performance variable. In the previous analysis the standard deviation of descriptive statistics was 1.94763 where the standard deviation rate was far greater than the standard error estimate of only 1.25741

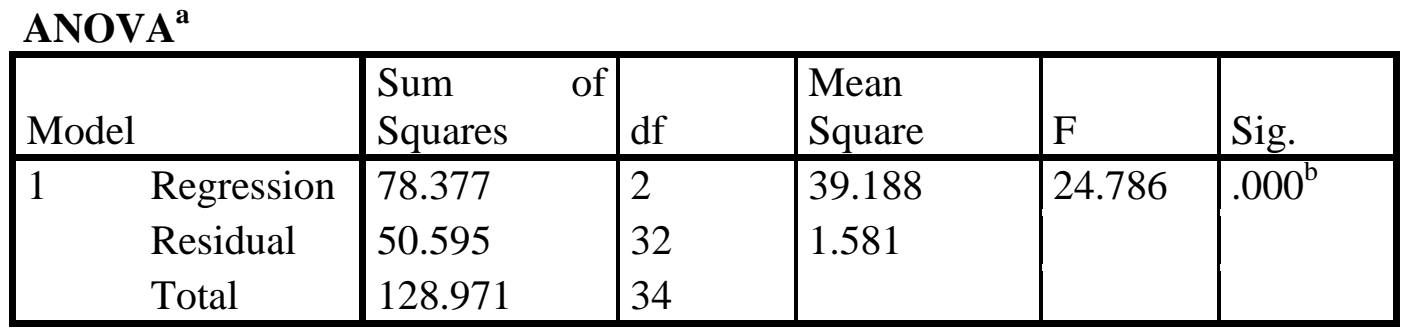




\begin{tabular}{|c|c|c|c|c|c|c|c|c|c|c|c|c|}
\hline \multirow{2}{*}{$\begin{array}{l}\text { M } \\
\text { od } \\
\text { el }\end{array}$} & \multicolumn{3}{|c|}{$\begin{array}{l}\text { Unstandardize } \\
\text { d Coefficients }\end{array}$} & \multirow{2}{*}{\begin{tabular}{|l}
$\begin{array}{l}\text { Standardi } \\
\text { zed } \\
\text { Coefficie } \\
\text { nts }\end{array}$ \\
\\
Beta \\
\end{tabular}} & \multirow[b]{2}{*}{$\mathrm{t}$} & \multirow[b]{2}{*}{ Sig. } & \multicolumn{3}{|c|}{ Correlations } & \multicolumn{2}{|c|}{$\begin{array}{l}\text { Collinearity } \\
\text { Statistics }\end{array}$} & \\
\hline & B & & & & & & $\begin{array}{l}\text { Zero- } \\
\text { order }\end{array}$ & $\begin{array}{l}\text { Partia } \\
1\end{array}$ & Part & $\begin{array}{l}\text { Tolera } \\
\text { nce }\end{array}$ & VIF & \\
\hline \multicolumn{3}{|c|}{ (Constant) } & $\begin{array}{l}-159 \\
.\end{array}$ & .805 & & -.197 & .845 & & & & & \\
\hline \multirow{2}{*}{\multicolumn{3}{|c|}{$\begin{array}{l}\text { COMPENS } \\
\text { ATION } \\
\text { MOTIVATI }\end{array}$}} & .646 & .252 & .697 & 2.568 & .015 & .779 & .413 & .284 & .166 & 6.015 \\
\hline & & & .085 & .258 & .089 & .328 & .745 & .726 & .058 & .036 & .166 & 6.015 \\
\hline
\end{tabular}

a. Dependent Variable: PERFORMANCE

b. Predictors: (Constant), MOTIVATION, COMPENSATION

In this table, there is a substantial (significant) effect of compensation (X1) and motivation (X2) simultaneously (together) on the performance (Y). F value (f arithmetic) of 24,786 and (significant level) sig $=0,000$

In the coefficient table column B in constants -159 , the compensation is 646 and the motivation is 0.085 . Based on the data above, it can be said that: a constant of -159 and a regression coefficient of X1 0.085 and a coefficient of X2 of 0.085 .

\section{Variable Operational Definition}

1. Compensation (X1)

Compensation is all income received by employees in the form of money, direct or indirect goods issued by PT Daya Anugrah Mandiri Samarinda in return for employee performance. Indicators used to measure compensation (Simamora, 2004: 442) are:

- Satisfied with basic salary

- Satisfied with work facilities

- Satisfied with allowance

2. Motivation (X2)

Motivation is a process that moves or encourages employees of PT Daya Anugrah Mandiri Samarinda in achieving the expected goals. Indicators used to measure motivation (George \& Jones, 2005: 175) are:

- Motivated to work

- Trying to get the job done

- Continue to work persistently despite any problems

3. Employee Performance (Y)

Employee performance is the quantity and / or quality of work produced by employees of PT Daya Anugrah Mandiri Samarinda such as the standard of work, targets set during a certain period that are guided by norms, standard operating procedures, criteria and functions that have been set or applicable in the company. The indicators used to measure employee performance (Bangun, 2012: 233) are:

- Number of jobs produced

- The quality of the work produced

- Timeliness of completing work

- Attendance on working days and hours

- Ability to work together 
International Journal of Economics, Business and Accounting Research (IJEBAR)

Peer Reviewed - International Journal

Vol-4, Issue-1, 2020 (IJEBAR)

E-ISSN: 2614-1280 P-ISSN 2622-4771

https://jurnal.stie-aas.ac.id/index.php/IJEBAR

\section{Conclusion and Suggestion}

\subsection{Conclusion}

Based on the results of this research, several conclusions can be drawn which can be used to answer the problems that have been formulated in this study:

1. Compensation has a positive and significant effect on employee performance

2. Motivation has a positive and significant effect on employee performance

\subsection{Suggestion}

From the conclusions, the author provides advices for the company:

1. Motivation provided in the automotive sector is quite high, the company should maintain it / be further enhanced. For example, having a vacation event with other employees. This togetherness event can improve social relations between employees and increase employee morale in working to provide the best performance. The company also needs to provide training to employees who have the potential to further improve their performance. The higher motivation will encourage employees to give better performance.

2. Compensation given by the company to employees is classified as moderate, so the company should give awards to the division that is able to show the best performance. Giving awards to each particular division will increase cooperation between employees. It can also create healthy competition between divisions and employees.

\section{Reference}

Abdullah, M. 2014. Manajemen dan Evaluasi Kinerja Karyawan. Penerbit Aswaja Pressindo. Yogyakarta.

Hasibuan, M.S.P. 2012. Manajmen Sumber Daya Manusia. Edisi Revisi. Penerbit Bumi Askara. Jakarta.

Suwati, Y. 2013. Pengaruh Kompensasi Dan Motivasu Kerja Terhadap Kinerja Karyawan Pada PT. Tunas Hijau Samarinda. e-Journal Ilmu Administrasi $\quad$ Bisnis. Vol 1 (1): 41-45.

Kasenda, R. (2013). Kompensasi dan motivasi pengaruhnya terhadap kinerja karyawan pada PT Bangun 45 Wenang Beverage Company Manado. Jurnal EMBA, 1(3), 853-859.

Bangun, W. (2012). Manajemen sumber daya manusia. Jakarta: Erlangga.

Wibowo. 2016. Manajemen Kinerja, Edisi Kelima, PT RajaGrafindo Persada. Jakarta. 